\section{PENDAMPINGAN PENGOLAHAN LIMBAH PLASTIK MINUMAN KEMAS- AN MENJADI KERAJINAN TANGAN}

\author{
Haeranal*, Nurbiah Tahir $^{*}$, \\ Fatmawada Sudarman², Ahmad \\ Harakan ${ }^{3}$
}

1)Program Studi llmu Administrasi Negara, Universitas Muhammadiyah Makassar

2)Program Studi IImu Administrasi Publik, IISIP Yapis Biak, Papua

3) Program Studi IImu Pemerintahan, Universitas Muhammadiyah Makassar

$\begin{array}{lll}\text { Article history } & \\ \text { Received : } & 11-09-2021 \\ \text { Revised } & 26-01-2022 \\ \text { Accepted : } & 11-02-2022\end{array}$

\author{
*Corresponding author \\ Haerana \\ Email: Haerana@unismuh@ac.id
}

\begin{abstract}
Abstrak
Limbah plastik dapat dikreasikan menjadi sejumlah kerajinan tangan berupa keranjang belanja, tempat tisu, tempat minuman gelas, aksesoris dan hiasan rumah lainnya yang tentu saja memiliki nilai jual. Tujuan kegiatan ini adalah untuk memberdayakan masyarakat melalui peluang usaha pemanfaatan limbah plastik sehingga akhirnya mendapat tambahan penghasilan. Target mitra yaitu masyarakat yang minat berwirausaha. Kegiatan PKM dijalankan melalui tahap, yaitu 1) persiapan dengan sosialisasi kegiatan kepada masyarakat, untuk memudahkan koordinasi maka akan dibentuk kelompok usaha kecil 2) pelaksanaan dilakukan dengan cara pelatihan dilengkapi dengan praktek langsung 3) pendampingan dilakukan selama pelaksanaan kegiatan dilakukan baik dalam proses produksi, inovasi produk, administrasi dan akuntansi sederhana, maupun pemasaran. Proses pemasaran dilakukan secara offline dan online. Dari hasil penyebaran kuesioner kepada peserta setelah PKM ini dilaksanakan menunjukkan bahwa terdapat $80 \%$ peserta telah sangat baik memahami teknik pembuatan produk inovatif yang diajarkan dan terdapat $83 \%$ peserta telah memiliki tingkat pemahaman yang sangat baik terhadap penggunaan website/blog sebagai sarana pemasaran online.
\end{abstract}

Kata Kunci: Pemasaran Online; Pemberdayaan Masyarakat; Sampah Plastik

\begin{abstract}
Plastic waste can be created into several handicrafts in the form of shopping baskets, tissue holders, glass drink holders, accessories and other home decorations, which of course have a selling value. This activity aims to empower the community through business opportunities to utilize plastic waste so that they eventually get additional income. The main target of this activity is people interested in entrepreneurship. This activity is carried out through three stages, namely 1) preparation by socializing activities to the community, to facilitate coordination a small business group will be formed 2) implementation is carried out by means of training equipped with direct practice 3) assistance is carried out during the implementation of activities carried out both in the production process, product innovation, simple administration and accounting, as well as marketing. The marketing process is carried out offline and online. From the results of distributing questionnaires to participants after this PKM was carried out, it showed that $80 \%$ of participants had very good understanding of the techniques for making innovative products that were taught, and $83 \%$ of participants had a very good level of understanding on the use of websites/blogs as a means of online marketing.
\end{abstract}

Keywords: Online Marketing; Community Empowerment; Plastic Waste

\section{PENDAHULUAN}

Kesejahteraan masyarakat merupakan bukti nyata keberhasilan pembangunan yang diselenggarakan oleh pemerintah. Usaha Kecil Menengah (UKM) merupakan sektor yang berperan penting dalam pertumbuhan perekonomian masyarakat Indonesia (Sondakh et al., 2021). Kesejahteraan masyarakat dapat diusahakan sendiri dengan mengembangkan kreativitas. Simon et al. (2018) menyatakan bahwa kreativitas didasarkan kepada kemampuan yang dimiliki seseorang dalam berfikir dan bertingkah laku. Kreativitas inilah yang kemudian dapat melahirkan pemecahan masalah yang dihadapi. Di Masa Pandemi Covid 19 yang melemahkan perekonomian masyarakat dibutuhkan kreativitas agar masyarakat dapat tetap berpenghasilan untuk dapat bertahan hidup. Menurut Arico \& Jayanthi (2018) bahwa kreasi kreatif dari 
sampah plastik dikenal memiliki nilai jual tinggi, untuk itu dapat mendapatkan keuntungan.

Hasil penelitian menunjukkan bahwa Kecamatan Rappocini memiliki total timbulan sampah sebesar 460.69 m3 (Jumran, 2017). Penyebab utama besarnya Konsumsi yang tinggi menyebabkan peningkatan volume sampah. Konsumsi makanan cepat saji menyebabkan lebih banyak sampah baik dari segi volume maupun variasinya. Khususnya sampah plastik karena plastik kini menjadi alternatif kemasan yang populer mulai dari kantong plastik pusat perbelanjaan hingga botol plastik yang terbuat dari makanan dan minuman olahan (Sunarsi et al., 2019). Berdasarkan hasil observasi di lokasi target mitra PKM, terlihat bahwa masyarakat sudah sangat memahami teknik pemisahan sampah antara sampah organik dan anorganik, hal ini dikarenakan masyarakat mendapat sosialisasi dan pelatihan dari Tim Bank Sampah Jipang 04 yang sudah lama terbentuk di lingkungan tersebut. Dan dari proses kegiatan pemilahan sampah tersebut dibentuklah kelompok kerajinan tangan. Kelompok kerajinan tangan berbahan plastik kemasan minuman di kecamatan rappocini Kota Makassar, setelah dilakukan observasi oleh Tim PKM, maka permasalahan mitra antara lain:

a. Keterbatasan bahan baku. Selama ini limbah plastik yang digunakan berasal dari lingkungan sekitar yang jumlahnya sangat sedikit, hal ini dikarenakan kurangnya modal untuk membeli limbah plastik dari pengepul.

b. Usaha kerajinan tangan tersebut tidak dikelola dengan baik dari aspek manajemennya maupun administrasinya.

c. Pemasaran produk tidak dilakukan secara maksimal baik secara offline maupun online, sama sekali tidak ada pemanfaatan teknologi internet.

d. Hasil kreasi kerajinan tangan dari limbah plastik tersebut masih terbatas bentuknya sehingga perlu dilakukan modifikasi bentuk yang lebih kreatif.

Adapun indikator pencapaian target dan luaran dari PKM pengolahan limbah plastik ini adalah:

a. Menjaga lingkungan sekitar dengan memanfaatkan limbah plastik yang sulit terurai oleh tanah.

b. Menciptakan peluang usaha bagi masyarakat yang memiliki ketertarikan pada dunia usaha kerajinan tangan.

c. Meningkatkan pendapatan masyarakat yang tentunya akan searah dengan peningkatan kesejahteraannya.

d. Mengajarkan pada masyarakat ilmu pemasaran, sehingga apapun produknya kelak mereka telah mengetahui bahwa suatu produk dapat dipasarkan menembus batas wilayah manapun (online).

\section{METODE PELAKSANAAN}

Kegiatan pengabdian ini mempunyai tahapan yang tergambarkan dalam bagan alur kegiatan yang terdiri dari tahap sosialisasi, tahap pendampingan dan tahap evaluasi (Gambar 1). Sejumlah rencana prosedur Kegiatan yang dilakukan adalah mengidentifikasi potensi pelaku dan mitra terkait dengan jumlah dan keahlian tenaga kerja ketersediaan bahan baku peralatan manajemen pasar dan lingkungan internal lainnya serta lingkungan eksternal yang terkait dengan operasi bisnis; analisis kebutuhan mitra; dan perencanaan penyusunan rencana kerja berbasis permasalahan mitra.

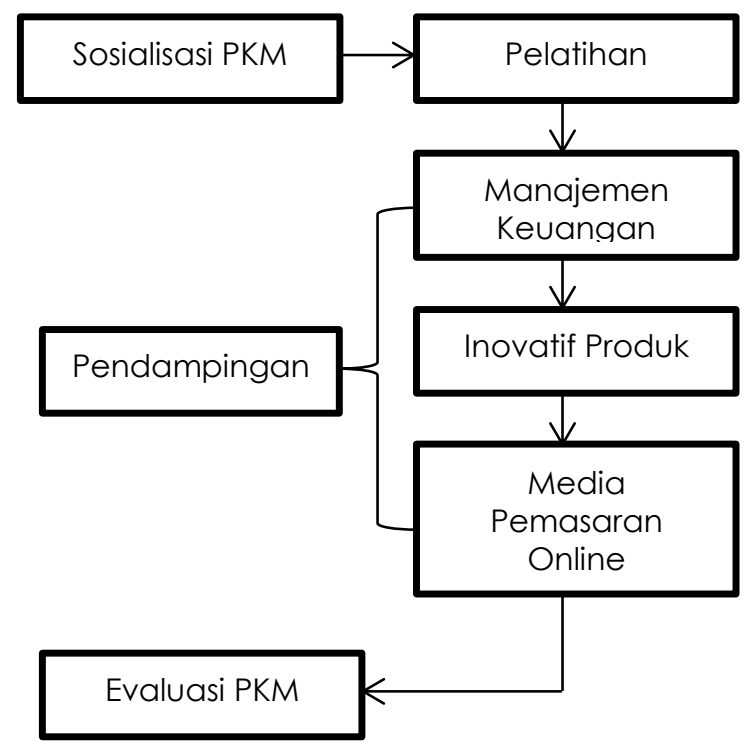

Gambar 1. Alur kegiatan PKM

\section{PEMBAHASAN}

Kegiatan pelatihan dihadiri oleh 15 orang dan para peserta sangat bersemangat dalam mengikutinya. Hal ini dapat dipahami sebab peserta dari pelatihan ini adalah ibu-ibu rumah tangga yang berkeinginan untuk mengembangkan usaha kerajinan tangan yang mereka geluti.

\section{Pelatihan Manajemen Keuangan (Pembukuan)}

Sebagian besar pengusaha/wirausahawan lebih mementingkan konsep usaha dan berfikir pengelolaan keuangan adalah sesuatu yang menyertai bisnis. Menurut pebisnis bahwa jika bisnis baik keuangan akan mengikuti. Jika bisnis itu menguntungkan uang akan bertambah terus. Asumsi ini benar tetapi bisa menyesatkan. Memang benar bahwa sumber kas bisnis adalah pendapatan dan laba. Tetapi bisnis tidak hanya tentang 
menghasilkan uang tetapi juga tentang pengeluaran dan tata kelolanya.

Tata kelola keuangan lebih dari sekedar manajemen kas tetapi bagaimana mengatur aset untuk mendatangkan profit dan menggunakan sumber daya modal untuk membiayai bisnis. Prinsipprinsip pengelolaan keuangan juga harus digunakan usaha kecil dan menengah. Dalam materi kedua (2) ini, mitra diberikan pelatihan langsung tata cara menyusun pembukuan, dengan memberikan soal latihan (Gambar 2). Tujuan pelatihan pembukuan ini agar kedepannya mitra dapat melakukan pencatatan dan pembukuan semua transaksi terkait bisnis usaha kecil yang ditekuninya. Dalam pengelolaan keuangan, pengrajin belajar memahami pembukuan sederhana menentukan harga jual suatu produk dan mengetahui untung/rugi (Fitriana, 2020).

Pelatihan pembukuan diharapkan dapat memecahkan permasalahan mitra terkait catatan keuangan pemasaran/manufaktur dan pengemasan online sehingga manajemen bisnis akan lebih baik (Puspita et al., 2020). Pendampingan keuangan diharapkan pihak mitra lebih menata diri dalam hal pembukuan sehingga akan memberikan kejelasan akan pengelolaan keuangan bisnis mereka.

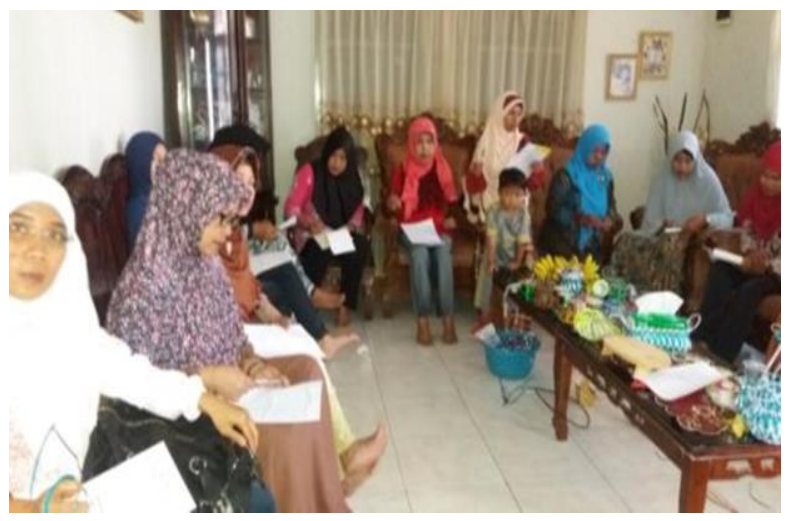

Gambar 2. Pelatihan pembukuan

\section{Pelatihan Inovatif Produk}

Pelatihan inovatif produk dalam kegiatan pengabdian kepada masyarakat ini bertujuan untuk memberikan pelatihan sejumlah produk kerajinan yang baru dan inovatif agar jenis produk kelompok pengrajin yang menjadi mitra dapat bervariatif sehingga dapat bersaing dengan kelompok pengrajin dengan bahan baku yang sama. Pengembangan daya saing UMKM perlu terus dilakukan baik di perkotaan maupun di tingkat kabupaten dan desa (Harinie et al., 2020). Memiliki daya saing dan terus meningkatkan kinerja diperlukan dalam persaingan global yang dan hal ini sejalan dengan keinginan untuk mengantisipasi ketertinggalan (Mas'ud, 2017).
Pelatihan inovatif produk adalah salah satu upaya untuk melakukan diversifikasi hasil kerajinan. Menurut Khairani \& Pratiwi (2018) bahwa melalui diversifikasi produk dimaksudkan agar mengoptimalkan omset penjualan. Diversifikasi yang baik adalah yang dilakukan untuk tujuan peningkatan kualitas produk.

Produk pertama mitra masih sangat sederhana, bahan baku plastiknya belum dilapisi dengan kawat pita warna warni (Gambar 3). Upaya untuk menciptakan produk inovatif maka dikembangkanlah ide mempercantik tampilan dasar dari bahan baku kerajinan tersebut kemudian dilapisi pita kawat warna warni sehingga produk yang dihasilkan dapat lebih menarik (Gambar 4). Dengan inovatif produk ini maka diharapkan secara kuantitas produk dari mitra dapat bertambah jenisnya dan diharapkan pula dapat memperluas pemasaran dari mitra.

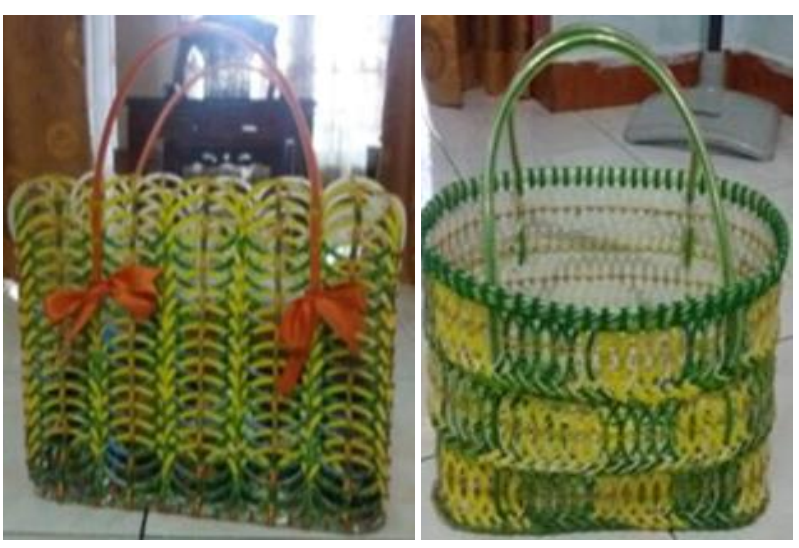

Gambar 3. Keranjang belanja

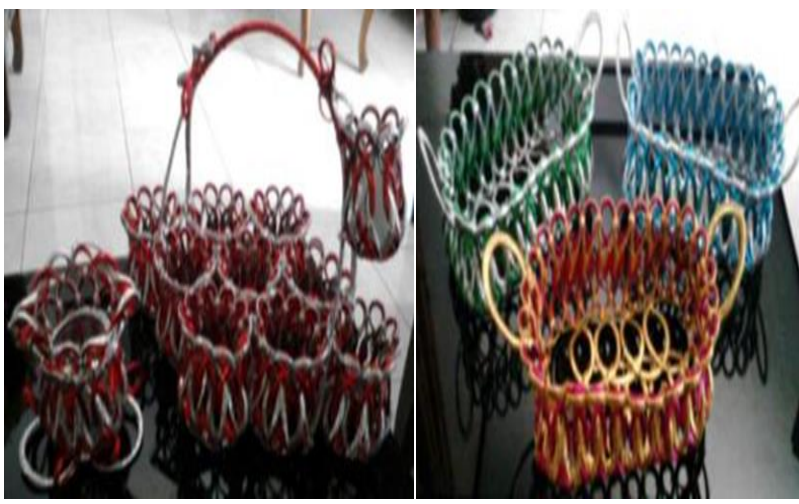

Gambar 4. Hasil pelatihan inovatif produk

Berdasarkan hasil penyebaran kuesioner kepada peserta untuk mengukur tingkat penguasaan atau kemahiran peserta atas tata cara pembuatan produk-produk inovatif yang sudah diajarkan maka terlihat bahwa terdapat $80 \%$ peserta telah sangat baik memahami teknik pembuatan produk inovatif tersebut (Gambar 5). 


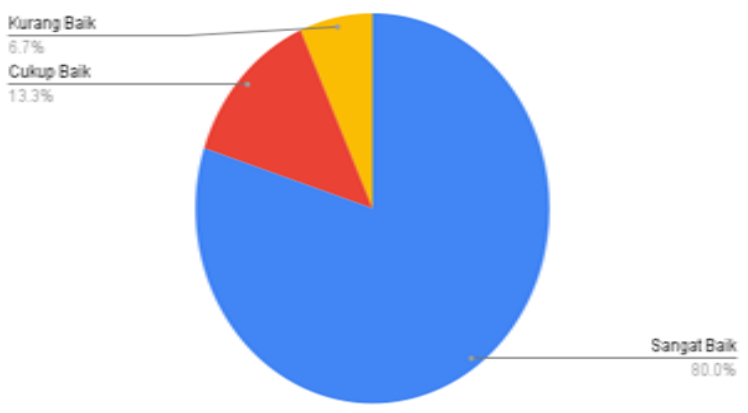

Gambar 5. Hasil olahan kuesioner

\section{Pelatihan Pembuatan Website/Blog Sebagai Media Pemasaran Online}

Sejumlah hasil penelitian menunjukkan bukti keefektifan media internet sebagai sarana pemasaran (Harto et al., 2019). Setelah mengadakan diskusi dengan para peserta pelatihan maka atas permintaan mereka maka Website yang akan dibuat adalah website gratis (blogspot) dengan pertimbangan bahwa pada tahap awal ini mereka masih dalam tahap belajar aplikasinya, bagaimana mereka masuk ke dasbor blogger dan tata cara untuk upload langsung maupun tidak langsung artikel yang mereka inginkan untuk di publikasikan ke publik. Web blog gratis ini jika mereka terlalu sibuk sehingga sempat melupakan blognya maka blog ini akan tetap dapat diakses oleh publik sedangkan jika dibuatkan website dengan domain berbayar seperti misalnya .com maka jika satu tahun kemudian tidak memperpanjang domainnya maka secara otomatis websitenya akan tidak dapat di akses lagi. Berdasarkan kenyataan tersebut maka pihak mitra lebih memilih blog gratis (Gambar 6) dan akan meninjau perkembangannya selama 3 (tiga) bulan.

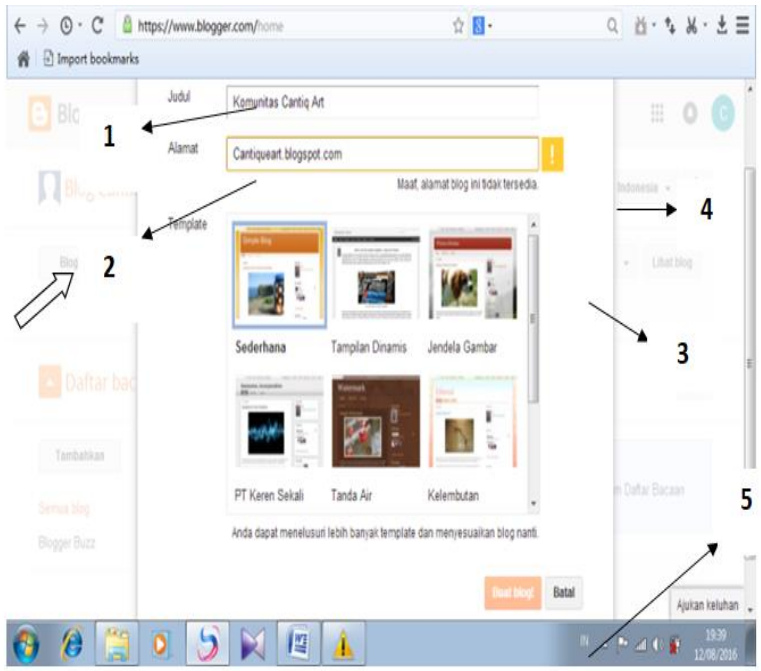

Gambar 6. Pembuatan blogspot
Langkah pembuatan blogspot adalah (1) Silahkan isi nama blognya; (2) Isikan dengan alamat blog anda; (3) Pilihlah template yang anda sukai; (4)Berisikan keterangan apakah alamat blog yang anda pilih tersedia atau tidak; dan (5) Tekan tombol ini jika semua item sudah dianggap benar. Setelah memilih tombol "Buat Blog", maka telah berhasil membuat web blognya yang berjudul "www. Cantiqueart.blogspot.com" (Gambar 7).

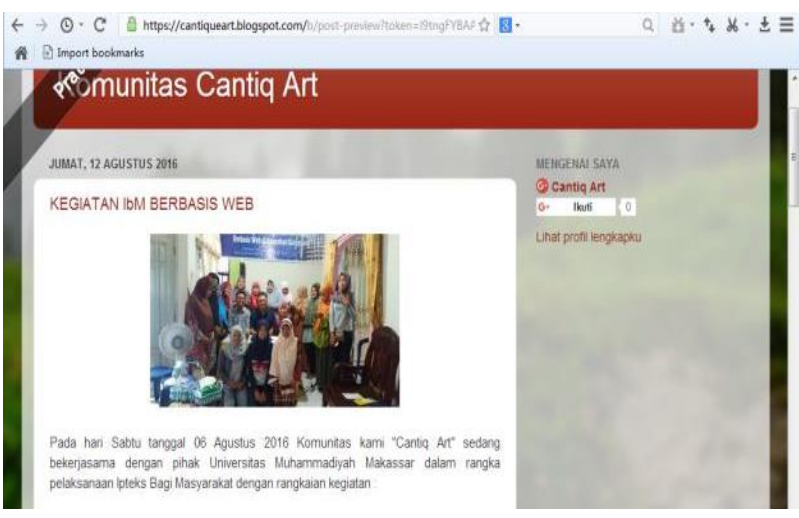

Gambar 7. Tampilan web blog

Penggunaan e-commerce dan inovasi design adalah bagian dari upaya peningkatan pemasaran produk. Negara maju fokus pada kreativitas dan perekonomian stabil tanpa ketergantungan pada aspek alam dan tanah (Nasrullah et al., 2016). Menjalin kerjasama dengan e-commerce dan kreatif mendesain merupakan solusi pemasaran produk terbaik (Ridho et al., 2019).

Strategi pemasaran merupakan bagian dari gagasan/perencanaan yang digunakan untuk promosi produk-produk tertentu baik barang atau jasa, sehingga bisa dikenal seluruh masyarakat dan mendapatkan umpan balik berupa nilai keuntungan yang lebih tinggi dari keuntungan sebelumnya (Tantra \& Mahyuni, 2021). Usaha kecil menengah harus sangat kreatif menangkap peluang pasar. Trik penjualan adalah aspek yang menentukan sukses dan gagalnya usaha, pemasaran yang baik mendatangkan keuntungan yang baik (Siregar et al., 2021). Menurut Wardani \& Suminar (2018) bahwa teknik promosi offline membutuhkan biaya besar sedangkan pemasaran online dapat memudahkan pengrajin mendapatkan customer dengan cepat. Pebisnis mulai mengupayakan mengkombinasikan sejumlah indikator dalam usahanya mengklasifikasikan kelompok sasaran yang lebih kecil dan dimaknai dengan lebih baik (Winarto et al., 2020).

Berdasarkan pengisian kuesioner sebagai evaluasi atas pelatihan yang diberikan maka menunjukkan bahwa terdapat $83 \%$ peserta telah memiliki tingkat pemahaman yang sangat baik 
terhadap penggunaan website/blog sebagai sarana pemasaran online (Gambar 8).

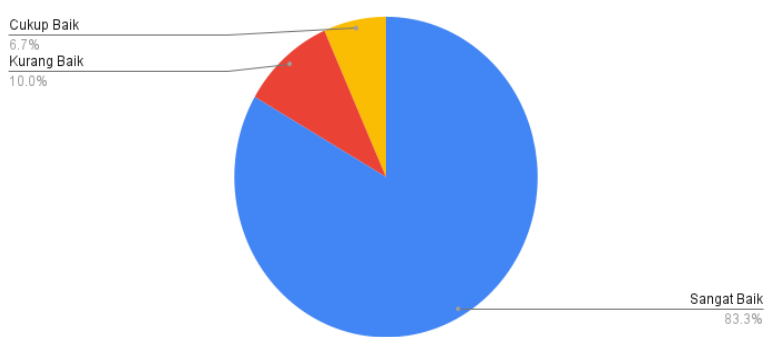

Gambar 8. Hasil olahan kuesioner

\section{KESIMPULAN}

Kegiatan pelatihan ini berjalan dengan baik dengan berdasarkan nilai evaluasi yang ditunjukkan pada pembagian kuesioner kepada peserta yaitu 80 $\%$ peserta telah sangat baik memahami teknik pembuatan produk inovatif yang diajarkan dan $83 \%$ peserta telah memiliki tingkat pemahaman yang sangat baik terhadap penggunaan website/blog sebagai sarana pemasaran online. Hasil evaluasi kinerja masuk dalam kategori sangat baik, dengan pemaknaan bahwa seluruh peserta memahami semua aspek pelatihan yang sudah dilaksanakan. Pengolahan limbah plastik menjadi kerajinan merupakan langkah yang tepat sebagai salah satu upaya menyelamatkan lingkungan dan peningkatan penghasilan masyarakat. Materi pelatihan selanjutnya ditargetkan pada perluasan pemasaran online dengan memanfaatkan marketplace, media sosial dan sejumlah aplikasi e-commerce lainnya di Indonesia sehingga semakin dikenalnya produk daur ulang tersebut maka semakin cepat pengurangan limbah plastik dari minuman kemasan.

\section{UCAPAN TERIMA KASIH}

Kami menyampaikan terimakasih kepada Lembaga Penelitian Pengembangan dan Pengabdian Masyarakat (LP3M) Universitas Muhammadiyah Makassar atas hibah internal yang telah diberikan dan kepada mitra PKM atas partisipasinya pada kegiatan PKM yang dilaksanakan.

\section{DAFTAR PUSTAKA}

Arico, Z., \& Jayanthi, S. (2018). Pengolahan limbah plastik menjadi produk kreatif sebagai peningkatan ekonomi masyarakat pesisir. Martabe: Jurnal Pengabdian Kepada Masyarakat, 1(1), 1-6. https://doi.org/10.31604/jpm.v1i1.1-6

Fitriana, R. (2020). Pelatihan Manajemen Pengelolaan Homestay di Desa Wisata Cikolelet, Serang, Banten. Wikrama Parahita: Jurnal Pengabdian Masyarakat, 4(1), 8-12. https://doi.org/10.30656/jpmwp.v4il.2059

Harinie, L. T., Hukom, A., \& Juma'eh, J. (2020). Pendampingan dalam Memasarkan Produk Hasil
Usaha UKM melalui Penggunaan Media Sosial di Kabupaten Gunung Mas Kalimantan Tengah. Engagement: Jurnal Pengabdian Kepada Masyarakat, $\quad 4(1), \quad 51-59$. https://doi.org/10.29062/engagement.v4il.179

Harto, D., Pratiwi, S. R., Utomo, M. N., \& Rahmawati, M. (2019). Penerapan Internet Marketing Dalam Meningkatkan Pendapatan Pada UMKM. JPPM (Jurnal Pengabdian Dan Pemberdayaan Masyarakat), 3(1),

39-45. https://doi.org/10.30595/jppm.v3i1.3033

Jumran, S, (2017). Efektivitas Pola Penanganan Sampah di Kota Makassar. Skripsi. Universitas Hasanuddin. http://digilib.unhas.ac.id/opac/detailopac? $i$ id=34493

Khairani, S., \& Pratiwi, R. (2018). Peningkatan Omset Penjualan Melalui Diversifikasi Produk dan Strategi Promosi Pada UMKM Kerajinan Souvenir Khas Palembang. CARADDE: Jurnal Pengabdian Kepada Masyarakat, $\quad 1(1), \quad 36-43$. https://doi.org/10.31960/caradde.v1i1.18

Mas' ud, M. (2017). Pemanfaatan Teknologi Sistem Informasi untuk Meningkatkan Penjualan Hasil Produk UMKM Logam di Kota Pasuruan. Engagement: Jurnal Pengabdian Kepada Masyarakat, 1(2), 185-197. https://doi.org/10.29062/engagement.v1i2.14

Nasrullah, D., Hidayatullah, A., \& Unggul WP, S. (2016). Pendampingan E-Commerce dan Pendidikan di Cerme Kecamatan Ngimbang Lamongan. Aksiologiya: Jurnal Pengabdian Kepada Masyarakat, 1 (1), https://doi.org/10.30651/aks.v1i1.301

Puspita, V. A., Veranita, M., \& Gunardi, G. (2020). Perbaikan Tata Kelola Bisnis UMKM Kerupuk Kulit Singkong menuju Ketahanan Bumdes Jagabaya. Wikrama Parahita : Jurnal Pengabdian Masyarakat, 4 (1), 29-37. https://doi.org/10.30656/jpmwp.v4i1.2137

Ridho, M. R., Simanjuntak, P., \& Ningsih, D. (2019). PKM Ecommerce, Packaging Design dan Manajemen Pemasaran untuk Usaha Kuliner Kota Batam. Wikrama Parahita: Jurnal Pengabdian Masyarakat, 3(1), 21. https://doi.org/10.30656/jpmwp.v3i1.1180

Simon, Z. Z., Ismail, V. Y., \& Zain, E. (2018). Pemberdayaan Ibu-lbu Rumah Tangga Melalui Pelatihan Kerajinan Makrame dalam Membuat Benda Fungsional Gantungan Pot. Wikrama Parahita: Jurnal Pengabdian Masyarakat, 2(2), 51-54. https://doi.org/10.30656/jpmwp.v2i2.725

Siregar, S. A., Pristiyono, P., \& Prayoga, Y. (2021). Pendampingan Produksi Dan Strategi Pemasaran Industri Rumah Tangga Keripik Ubi Mana Lagi "Pak Jaim" Di Desa Gunung Selamat. JPKM: Jurnal Pengabdian Kepada Masyarakat, 72(2), 155-160. https://jurnal.unimed.ac.id/2012/index.php/jpkm/arti cle/view/23526

Sondakh, R. C., Kusrianti, N., \& Astri, F. (2021). Pendampingan Pembuatan Kreasi Cokelat untuk Pengembangan Industri Rumahan Desa Ginunggung, Kabupaten Tolitoli. Wikrama Parahita: Jurnal Pengabdian Masyarakat, 5(2), 132-138. https://doi.org/10.30656/jpmwp.v5i2.2645

Sunarsi, D., Kustini, E., Lutfi, A. M., Fauzi, R. D., \& Noryani, N. (2019). Penyuluhan Wirausaha Home Industry Untuk Meningkatkan Ekonomi Keluarga Dengan Daur Ulang 
Barang Bekas. BAKTIMAS: Jurnal Pengabdian Pada Masyarakat, $1(4)$,

188-193. https://doi.org/10.32672/btm.v1i4.1720

Tantra, P. F. E. ., \& Mahyuni, L. P. (2021). Pengembangan Strategi Pemasaran Kopi Rempah Desa Tista ( Redesta ) Dalam Meningkatkan Pendapatan Badan Usaha Milik Desa ( Bumdes ). Jurnal Pengabdian Kepada Masyarakat, 27(3), 218-225. https://jurnal.unimed.ac.id/2012/index.php/jpkm/arti cle/view/23737

Wardani, S., \& Suminar, Y. A. (2018). Pelatihan Manajemen
Web untuk Peningkatan Promosi pada KUD Tani Makmur Kecamatan Kasihan. Wikrama Parahita: Jurnal Pengabdian Masyarakat, 2(2), 79-88. https://doi.org/10.30656/jpmwp.v2i2.643

Winarto, J., Tjandrasa, B. B., Anatan, L., Sunjaya, A., \& Ardianto, N. (2020). Pengambilan Keputusan Strategis Jendela Alam Lembang: Perspektif Keuangan dan Strategi. Wikrama Parahita: Jurnal Pengabdian Masyarakat, 4 (1), $1-7$. 